\title{
A New Quantitative Determination Method for Aspirin Phenacetin, Cafein and Their Mixtures Using NMR Spectrometer
}

\author{
Aspirin, Fenasetin, Kafein ve Karışımlarının N M R Spekt- \\ rometri ile Yeni Bir Nicel Saptama Yöntemi \\ Ningur NOYANALPAN* Tuncel ÖZDEN*
}

There are several methods for the determination of aspirin, phenacetin and cafein quantitatively in their preparations. Conners ${ }^{1}$ has given many references for quantitative determination. The method mentioned in the NF XII ${ }^{2}$ is an extraction procedure therefore very time consuming and not suitable for routine applications, Parke et al. ${ }^{3}$ have used ir spectrophotometer for the quantitative determination. This method is faster and more accurate than the one mentioned in NF XII. N M R spectrometer has been used by Hollis ${ }^{4}$ for the quantative determination but the known sample used in his method is cafein whichcauses the calculations to be long and enough complicated. Therefore we have looked for another reference compound and decided to use succinic acid.

\section{EXPER I M EN TA L}

In this research the $\mathrm{nmr}$ spectrometer is a $\mathrm{T}-60$ Varian $60 \mathrm{MHz}$. instrument.

Operation: 10 tablets are weighed accurately and powdered. An accurate quantity of this powder which corresponds to $1 / 3$ of a tablet is weighed. To this powder, $25 \mathrm{mg}$ succinic acid, $2 \mathrm{ml}$ deutorated chloroform and $1 \mathrm{ml}$ deutorated dimethylsulfoxide is added. The

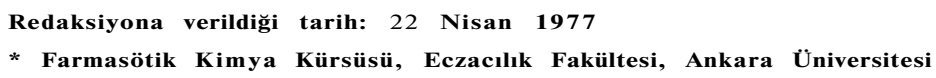


mixture is well stirred and then filtered through glass wool. $0.4-0.5$ $\mathrm{ml}$ of the filtrate is taken into an $\mathrm{nmr}$ tube and the spectrum is drown. The bands which are to be used for the quantitative determination are chosen and their integrals are scanned repeatedly and the average is found. The proper APC preparations contain cafein less then the others therefore starting with more powder increases the cafein concentration and thus the integral value resulting more accurate determinations. This has not been done in this research and still the results have allways shown an error less then $4 \%$.

\section{I S C US S I O N}

The $60 \mathrm{MHz} \mathrm{nmr}$ spectra of aspirin, phenacetin and cafein are the Spectra. I, II and III respectively. Spectrum. IV belongs to succinic acid and Spectrum. V belongs to the mixture of APC tablets and succinic acid. As mentioned before, the spectra of aspirin, phenacetin and cafein have been taken deutorated chloroform and the spectrum of succinic acid in deutorated dimethylsulfoxide and the spectrum of the mixture of APC tablets and succinic acid in deutorated chloroform and deutorated dimethylsulfoxide.

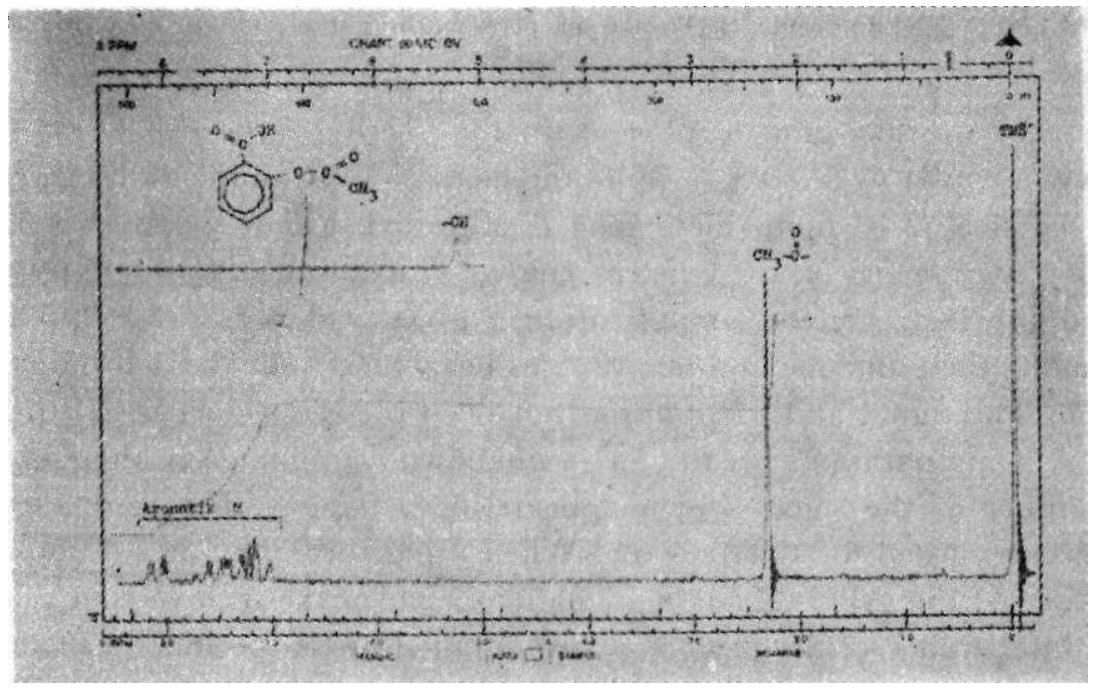

Spectrum. I. Aspirin, 60 M Hz nmr spectrum 
The sharp signal at $2.33 \mathrm{ppm}$ in the spectrum of Aspirin belongs to methyl group of ester moiety, the signals at $7.00-8.17 \mathrm{ppm}$ refer to phenyl hydrogens, the one at $10.47 \mathrm{ppm}$ refers to the proton of carboxyl group. Among these the one at $2.33 \mathrm{ppm}$ which is a sharp signal has been used for the determination.

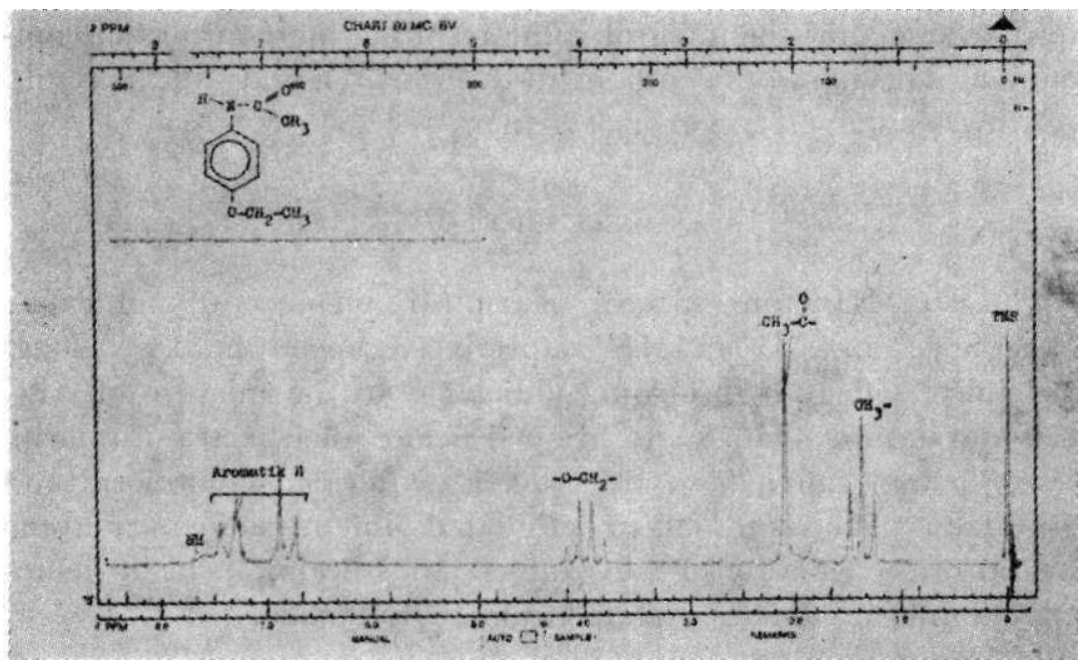

Spectrum. II. Phenacetin, $60 \mathrm{MHz}$ nmr spectrum

On the spectrum of phenacetin the methyl group of O-ethyl gives a triplet signal at $1.37 \mathrm{ppm}$, the methyl of the amide group gives a signal at $2.10 \mathrm{ppm}$. methylene of $\mathrm{O}$-ethyl group shows at 4.00 ppm, hydrogenes on the benzene ring give signals at $6.73-7.45 \mathrm{ppm}$ and the hydrogen on amide nitrogen gives a signal at $7.58 \mathrm{ppm}$. Among these the one at $4.00 \mathrm{ppm}$ has been chosen for the determination. The signal at $1.37 \mathrm{ppm}$ has not been preferred due to splitting in APC preparations because of an unknown coupling. Also there is a shoulder at the signal which appears at $2.10 \mathrm{ppm}$. Therefore they were discarded for this purpose. When using the signal at $4.00 \mathrm{ppm}$ starting from APC tablets it is mandatory to make a correction due to interference of the protons which situated at the position 7 of cafein. This correction can be realized very easily bv subtracting the methyl value of cafein at $3.58 \mathrm{ppm}$. 


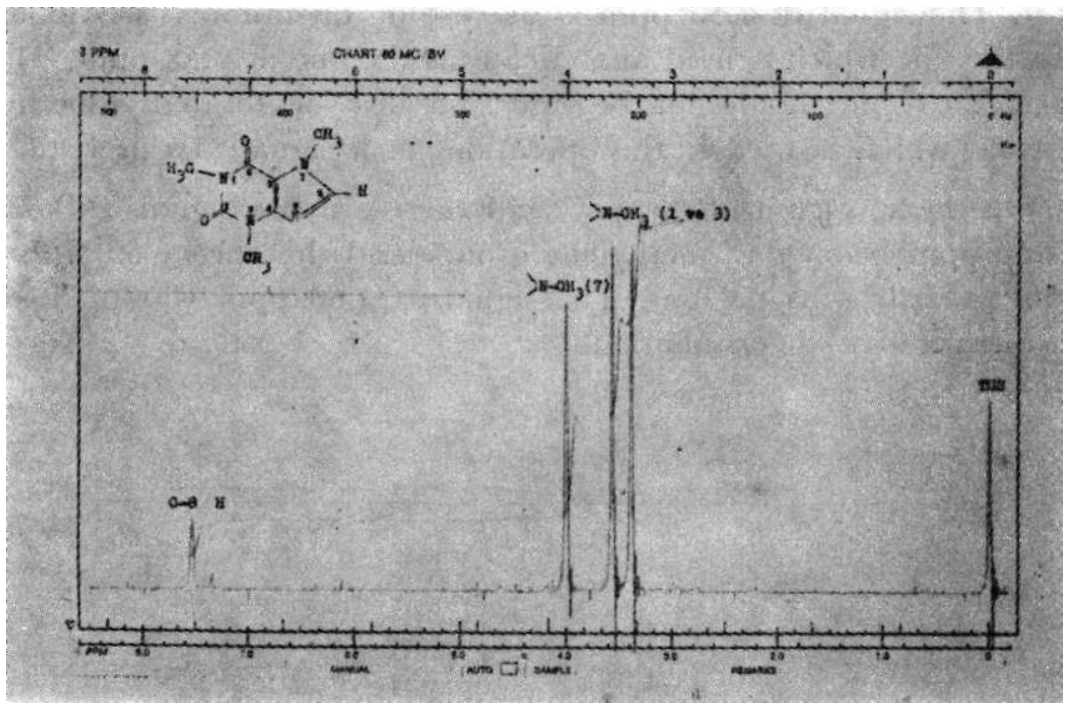

Spectrum. III. Cafein, 60 MHz nmr spectrum

In the spectrum of cafein the signals which are at 3.40 and 3.58 ppm belong to methyl groups attached to nitrogen atom number 1 and 3 , the signal at $4.00 \mathrm{ppm}$ belongs to methyl group on nitrogen num-

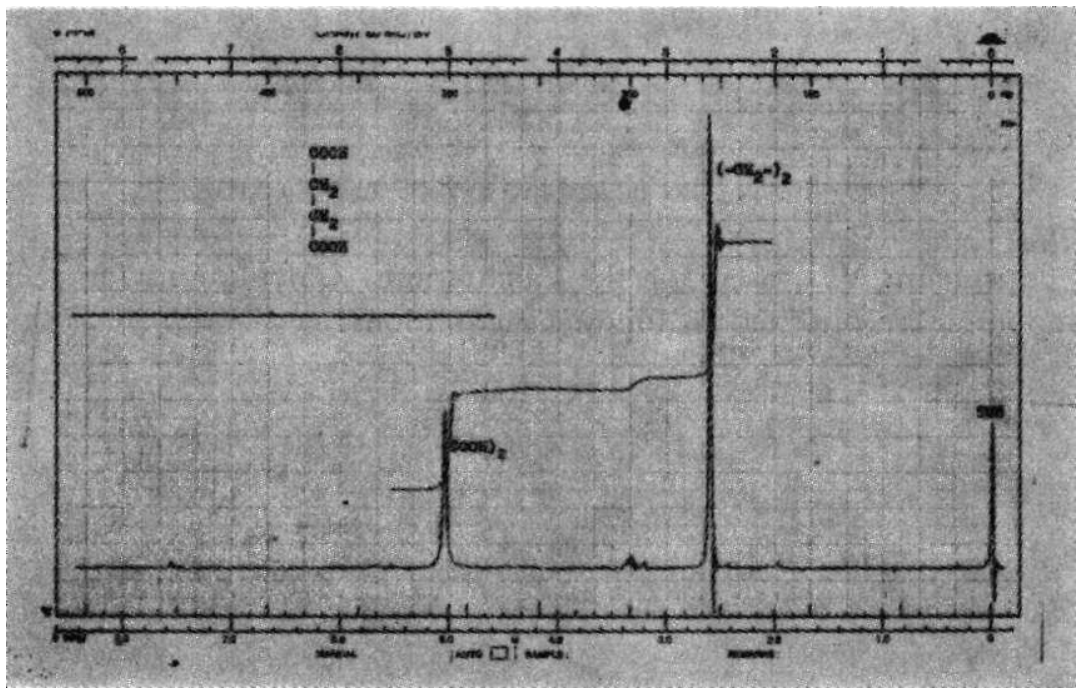

Spectrum. IV. Succinic acid, 60 MHz nmr spectrum 
ber 7. The signal at $7.53 \mathrm{ppm}$ is the proton on number 8. Among these the one which is used analytically is the one at $3.58 \mathrm{ppm}$. The one at $3.40 \mathrm{ppm}$ should not be used because deutorated dimethyl sulfoxide which is used in this operation has a signal at this region.

On the spectrum of succinic acid there are two signals the one at $2.60 \mathrm{ppm}$ belongs to methylene groups and the one at $5.03 \mathrm{ppm}$ belongs to carboxyl protons. The signal at $2.60 \mathrm{ppm}$ was used for the quantitative determination.

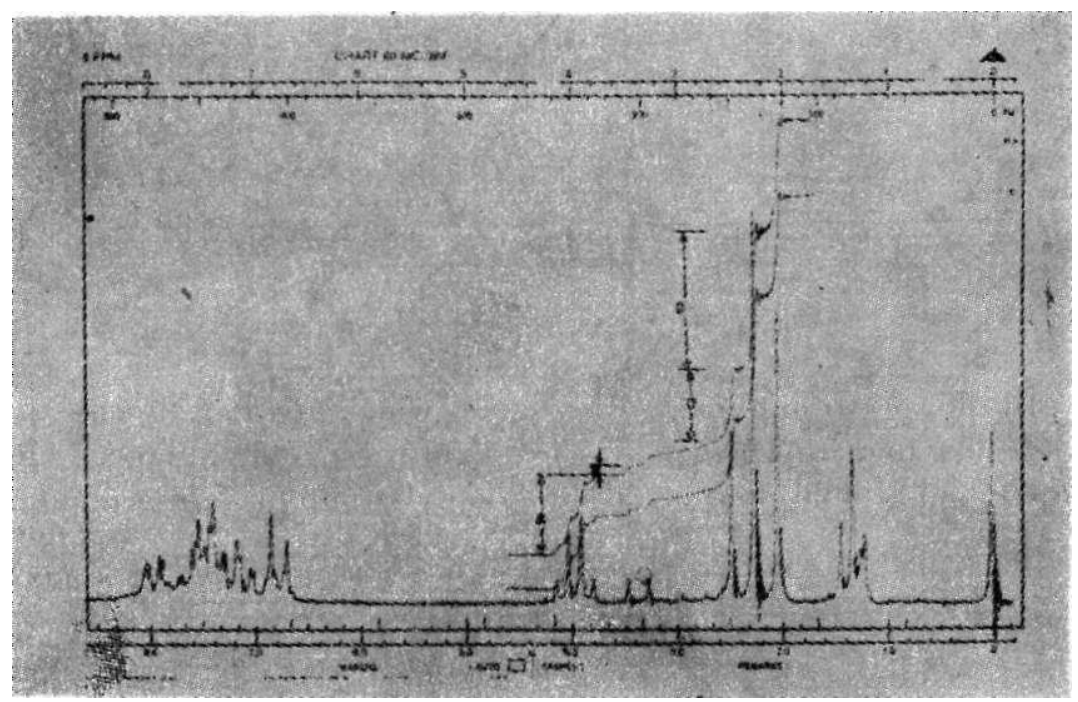

Spectrum. V. APC tablets and succinic acid, $60 \mathrm{MHz}$

Spectrum V is used for the calculations. Calculations for each compound are outlined in following equations: 
AS PI I RIN :

\begin{tabular}{|c|c|c|c|c|c|}
\hline mg Aspirin & D (integral value for Aspirin) & & $\mathbf{N}$ & Aspirin & \\
\hline mg Sample & C (integral value for Succinic acid) & $x$ & $\mathbf{N}$ & Succinic acid & $\mathbf{X}$ \\
\hline
\end{tabular}

QS quantity of succinic acid added (25 mg)

PHENACETTIN :

$\frac{m g \text { Phenacetin }}{\text { mg sample }} \quad \frac{(A-B)}{C} \times \frac{N \text { Phenacetin }}{\text { N Succinic acid }} \times$ QS QS quantity of succinic acid (25 mg)

GAFE I N :

$\frac{m g \text { cafein }}{m g \text { sample }} \frac{B}{c} \times \frac{N \text { cafein }}{N \text { Succinic acid }} \times$ QS QS quantity of succinic acid 525 mg)

N Aspirin $=\frac{\text { Moleculer weight of Aspirin }}{\text { number of protons at } 2.33 \mathrm{ppm}} \quad \frac{18016}{3} \quad 60.05$

N Phenacetin $\frac{\text { Molecular weight of Phenacetin }}{\text { number of protons at } 4.00 \mathrm{ppm}} \quad \frac{179.22}{2} \quad 89.61$

$N$ cafein $\quad \frac{\text { Molecular weight of Cafein }}{\text { number of protons at } 3.58 \mathrm{ppm}} \quad \frac{194.19}{3} \quad 64.73$

$N$ succinic acid $\quad \frac{\text { Molecular weight of Succinic acid }}{\text { number of protons at } 2.60 \mathrm{ppm}} \quad \frac{118.09}{4} \quad 29.52$ 
At the following Table the quantities of Aspirin, Phenacetin and cafein found with NMR spectroscopic method and the percent errors arc given

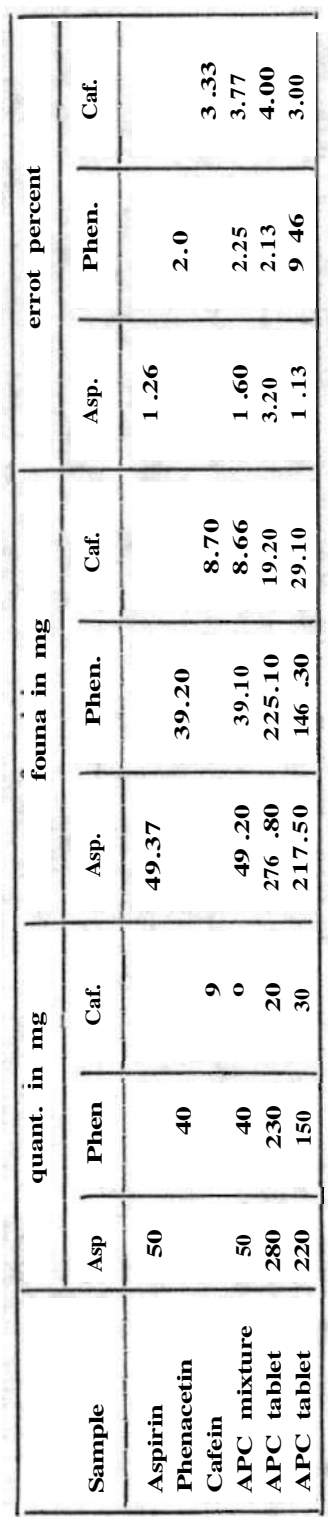


In this study, a new method has been designed for the quantitative determination of Aspirin, Phenacetin, Cafein and their mixtures in the commercial preparations. The quantitative determination methods for the mentioned compounds depend on time consuming extractions. In this research $\mathrm{nmr}$ spectrometer has been used by taking the integrals of a characteristic signal of each compound and comparing them with the integral intensity of a standard compound. Cafein had been used before as the standard compound with the nmr spectrometer. In our work succinic acid gave better results and easier calculation possibilities. The results obtained with this method show a superiority to those obtained with conventional methods.

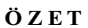

$\mathrm{Bu}$ çalışma ile tecimsel peparatlarda bulunan, Aspirin, Fenasetin ve Kafeinin nicel saptanması için yeni bir yöntem tasarlanmıştır. Adı geçen bileşiklerin nicel saptanmaları için kullanılan yöntemler uzun zaman alıcı tüketim işlemlerine dayanmaktadır. Bu çalışmada her bileşiğin karakteristik bir sinyalinin integralini alıp onu standard bir bileşiğin integral değeri ile karşılaştırarak nmr spektrometri kullanılmıştır. Daha önce standard bileşik olarak kafein kullanılmıştır. Çalışmamızda süksinik asitin daha iyi sonuç verdiği ve daha kolay hesaplama olanakları sağladığı saptanmıştır. Bu yöntemle elde edilen sonuçlar alışılagelmiş yöntemlerle elde edilenlerden daha iyidir.

\section{RE F E R E N C ES}

1. Conners. K. A., in "Pharmaceutical Analysis", Higuchi, I. and BrochmannHansen, E., I X, Interscience, New-York, 1961

2. National Formulary, 10 th Ed. American Pharmaceutical Association Phladelphia, 1955

3. Parke, T. V., Ribley, A. M., Kennedy, E. E., Hilty, W., Anal Chem. 23,953 (1951).

4. Hollis, D. P., Anal. Chem., 35, 1683 (1963) 